\title{
3 Research Square \\ Efficacy evaluation of methanolic extracts of Calpurnia aurea and Schinus molle plants against the cattle lice Linognathus vitulli
}

\author{
Abdi Abubeker \\ Wollo University \\ Alula Assen ( $\sim$ alula.alemayehu@wu.edu.et) \\ Wollo University \\ Ararsa Dhuguma \\ Haramaya University
}

\section{Research Article}

Keywords: Calpurnea aurea, Ethnoveterinary, lice, Adult Immersion Test, Schinus molle

Posted Date: February 22nd, 2021

DOl: https://doi.org/10.21203/rs.3.rs-257651/v1

License: (c) (1) This work is licensed under a Creative Commons Attribution 4.0 International License. Read Full License 


\section{Abstract}

Background Ectoparasites of livestock in general and lice in particular pose serious economic losses to the farmer, the tanning industry, and the country as a whole. Although the treatment of ectoparasites have been attempted by various chemical agents, the efficacy of the agents hampered by the development of drug resistance. Thus, Ethnoveterinary botanicals are an alternative control strategy for being sustainable and ecologically sound. Thus, this study aims to evaluate the louscidal activity of crude methanolic extracts of Calpurnea aurea and Schinus molle plants against the cattle lice, Linognathus vituli using the in vitro Adult Immersion Test (AIT). Six graded concentrations of the crude extracts, 6.25, 12.5, 25, 50, 100 and $200 \mathrm{mg} / \mathrm{ml}$, were tested at different time intervals, and temporal changes in tick viability were recorded for 24 hours. Results After $24 \mathrm{hrs}$ post-exposure, two higher concentrations (200 and $100 \mathrm{mg} / \mathrm{ml}$ ) of C. aurea extract caused $100 \pm 0.0 \%$ and $96.6 \pm 3.3 \%$ lice mortality, whereas S. molle extract caused $90 \pm 5.7 \%$ and $83.3 \pm 3.3 \%$ mortality, respectively. Louscidal activity varies with the type of plant extract, concentration and exposure time. After 24 hours of exposure to the extracts, the highest mortality was recorded for extracts from C. aurea with LC50 values of 8.83 $\mathrm{mg} / \mathrm{ml}$ compared to S.molle with LC50 values of $16.68 \mathrm{mg} / \mathrm{ml}$. Conclusions The louscidal activity of the plant extracts increases with increasing exposure time and concentration as well. Thus, the plant extracts could be used against Linognatus vituli as a potential alternative for the control of lice. Keywords: Calpurnea aurea, Ethnoveterinary, lice, Adult Immersion Test, Schinus molle

\section{Background}

Ethiopia is believed to have the largest livestock population in Africa. This livestock sector has been contributing a considerable portion to the economy of the country and still promising to rally round the economic development of the country. In Ethiopia, livestock production remains crucial and represents a major asset among resource-poor smallholder farmers by providing milk, meat, skin and manure, and traction force. This is because the country has the largest livestock number in Africa, which includes over 53.3 million cattle, 25.5 million sheep, and 22.7 million goats (1).

In Ethiopia, the livestock sector contributes $21 \%$ of GDP, among which the export of processed and semiprocessed skin and hide contributes $12 \%$ to $15 \%$ of export earnings. But, this figure has been deteriorating due to an increase in low-grade skin and hide, as a result of an infestation of ectoparasites which makes 10 to $20 \%$ of export skin and hides poor quality (2). Ectoparasites are very common and widely distributed in all agroecological zones in Ethiopia (3). Among ectoparasites, Lice are one of the most common and economically important ectoparasites of domestic animals (4).

Lice pose serious economic losses to the farmer, the tanning industry, and the country as a whole. Treatment of ectoparasites with various acaricide and insecticides like Diazinon, Fenvalerate, Deltamethrin, and Ivermectin has been attempted with different grades of success and rapid development of resistance (5). Another alternative control strategy could be phyto-therapy, an important component of ethnoveterinary medicine.

About $80 \%$ of people in the world today rely on folk (or traditional) medicine for treating both human and animal diseases (6). According to the United Nations Food and Agricultural Organization (FAO), the lack of drugs to treat diseases and infections results in losses of $30-35 \%$ in the breeding sector of many developing countries, where poor animal health remains the major constraint to increased production. These shortcomings have prompted 
the search for alternative ectoparasites control methods that are cheap and environmentally friendly like plant extracts (7).

The use of ethnoveterinary botanicals is sustainable and ecologically sound because the plants are locally available, potentially easy to be produced, locally processed, and used by farmers themselves (8). Medicinal plants can play an important role in the control of livestock's external infections. For the small farmers with low income, these infections can lead to enormous and insidious losses in the herds, by weakening the body of animals and by transmitting diseases often difficult to diagnose. Traditional veterinary medicine is very important in developing countries where conventional remedies for animal health care are inaccessible or unaffordable to poor rural farmers (9). Problems of service delivery to such groups are often exacerbated by a multitude of other factors and these factors have helped to maintain traditional treatment practices (10).

The use of botanicals for the control of disease is compatible with traditional practices in Africa, where most resource poor-farmers use plant materials to treat endoparasites and ectoparasites of livestock (11). In Ethiopia, traditionally the leave of Calpurnia aurea is used for the treatment of ectoparasites, syphilis, malaria, rabies, diabetes, hypertension, diarrhea, leishmaniasis, trachoma, elephantiasis, fungal diseases and different swellings, stomach-ache, bowel, and bladder disorders (12). Schinus species have been traditionally used as medicine by indigenous people throughout the tropics (13). In folk medicine, Schinus molle has been used due to its antibacterial, antiviral, topical antiseptic, antifungal, antioxidant, anti-inflammatory, anti tumoural, antispasmodic, analgesic properties, as well as a stimulant and an antidepressant (14). Strong antiparasitic and louscidal activity were recorded by leaf aqueous extract of Calpurnia aurea leaf ( $80 \%$ and $100 \%$ ) mortality at the concentration of $200 \mathrm{mg} \backslash \mathrm{ml}$ within $24 \mathrm{~h}$ of exposure respectively (15). Therefore, this study aimed to evaluate the in vitro louscidal efficacy of traditional medicinal plants used in ethnoveterinary medicine (EVM) practice in Ethiopia for control of lice, determine the LC50, LC90, and LC99 of the plant extracts and compare the efficacy of the two plant extracts on mortality of lice.

\section{Methods}

\section{Plant collection and preparation}

The study was used medicinal plants well known for their traditional utilization against lice infesting livestock in eastern Hararge, Ethiopia. Plants were selected based on scientific and ethnomedicinal information complemented with additional preliminary ethnobotanical surveys. The candidate plants for the experiment are Calpurnia aurea and Schinus molle. These plants are collected from Haramaya University botanical garden and taxonomical classification of the plants was carried out at Haramaya University, Department of Botany. The leaves were subsequently dried at room temperature in a ventilated room, milled to a fine powder using laboratory mortar and pestle, and stored in closed containers in the dark until used.

\section{Crude extract preparation}

The powdered specimen was subjected to extraction using $80 \%$ methanol by cold maceration technique. A total of $300 \mathrm{~g}$ of the pounded materials were soaked in extraction solvents with 1:4 in separate flasks and followed shaking by automatic orbital shaker for $24 \mathrm{hr}$. (16). The mixture was first filtered using gauze and then the filtrate passed through sterile filter paper (Whatman №. 3, Whatman Ltd. England). The filtered extract was concentrated 
in the rotary vacuum evaporator and dried in a hot air oven at a temperature of $45-50^{\circ} \mathrm{C}$. The filtrates were stored in capped labeled bottles and kept in the refrigerator at $4^{\circ} \mathrm{C}$ until use.

Parasites collection, transportation and identification

Lice were collected from infested cattle around Haramaya University and the parasites were maintained in plastic cups into which water-soaked cotton is placed to increase the humidity of the air found in the cups. The cup was covered by gauze to allow the free circulation of air into the cups and then the parasites transported to the Parasitology laboratory. The identification of the parasites was conducted under a stereo microscope. For this assay, only adult parasite and unsexed of lice were used. Species identification was done based on morphological identification keys given by (17).

\section{Adult immersion test}

Adult immersion test was carried out to evaluate the efficacy of the selected plant against Linognathus vituli. The plant extracts were diluted with distilled water to concentrations, 200, 100, 50, 25, 12.5 , and $6.25 \mathrm{mg} / \mathrm{ml}$ were prepared by serial dilution. The in vitro tests were carried out within $1 \mathrm{hr}$ after lice collection (18). The antiparasitic effect of each dilution was tested by immersing 10 lice in Petri dish containing $2 \mathrm{ml}$ of extract for 1 minute. The tests were carried out on ten unsexed lice per replications (11). Diazinon $0.1 \%$ and distilled water were used as positive and negative controls, respectively. The experiment was performed in triplicate and the Petri dish incubated at $27-28^{\circ} \mathrm{c}$ and $80 \%$ relative humidity for $24 \mathrm{hr}$. Lice in each Petri dish were closely observed for death under a stereo microscope at 30min, $1 \mathrm{hr}, 2 \mathrm{hr}$, $3 \mathrm{hr}, 6 \mathrm{hr}, 12 \mathrm{hr}$, and $24 \mathrm{hr}$ time intervals (19). Deaths of lice were defined as the lack of limb movement, and failure to respond when the legs were stroked with a needle. The percent mortality rates of lice were calculated as per the Abbots formula cited by (20).

Classification of Louscidal effects are followed as previously used in Melophagus ovinus by (21); as strong, mortality > 80\%; moderate, mortality $80-60 \%$; weak, mortality $60-40 \%$; little or no activity, mortality $<40 \%$.

\section{Data analysis}

Collected raw data were stored in the Microsoft Excel for windows 10 for data management. Data analysis was made using R 3.6.0 statistical package (22). The results of the study were expressed as a mean of mortality percentage \pm standard error (Mean \pm SE). Statistical significance was determined by one-way analysis of variance (ANOVA) with multiple comparison tests (Post Hoc/Tukey's test/HSD) to compare parameters within and between groups. Significant levels were set at $P<0.05$. The mortality data were subjected to probit analysis to calculate lethal concentration values $\left(\mathrm{LC}_{50}, \mathrm{LC}_{90}\right.$, and $\left.\mathrm{LC}_{99}\right)$ and lower and upper $95 \%$ confidence limits and Chi-square values were calculated using \{ecotox\} package of $\mathrm{R}$ statistical software.

\section{Results}

\section{Physical characteristics and yield of plant extracts}

After extraction with methanol the yields expressed as percentage (i.e. mg extracted from 300 mg of dry material) were obtained. The yields obtained were given in Table 1. 
Table 1: Physical characteristics and yields of the plant extracts

\begin{tabular}{|llllllll|}
\hline $\begin{array}{l}\text { Scientific } \\
\text { name }\end{array}$ & $\begin{array}{l}\text { Plant part } \\
\text { used }\end{array}$ & $\begin{array}{l}\text { Extract } \\
\text { solvent }\end{array}$ & $\begin{array}{l}\text { Weight of } \\
\text { powder }\end{array}$ & $\begin{array}{l}\text { Weight of } \\
\text { extract }\end{array}$ & Yield & $\begin{array}{l}\text { Extract } \\
\text { color }\end{array}$ & $\begin{array}{l}\text { Extracts } \\
\text { consistency }\end{array}$ \\
\hline C. aurea & Leaf & Methanol & $300 \mathrm{~g}$ & $12 \mathrm{~g}$ & $4 \%$ & $\begin{array}{l}\text { Redish } \\
\text { green }\end{array}$ & Semi-solid \\
\hline S. molle & Leaf & Methanol & $300 \mathrm{~g}$ & $18 \mathrm{~g}$ & $6 \%$ & $\begin{array}{l}\text { Dark } \\
\text { green }\end{array}$ & Semi-solid \\
\hline
\end{tabular}

\section{In Vitro louscidal activity of plant extracts}

In vitro louscidal activity test of Calpurnea aurea crude extract showed that the mortality of lice was gradually increased with increase post-exposure time and the concentration of the extracts as shown in figure 1.

The mean mortality of lice treated with different concentrations of the crude extract of Calpurnea aurea is shown in Table 2. The result has revealed that all concentrations of the extract result in the mortality of lice. Analysis of mortalities of lice in different concentrations of the plant extracts at different times of post-exposure reveals no significant difference $(P>0.05)$ between 200 and $100 \mathrm{mg} / \mathrm{ml}$ concentration of the extract as compared to the positive control, diazinon $0.1 \%$. Higher concentrations $(200$ and $100 \mathrm{mg} / \mathrm{ml})$ of the extract showed significant $(P<$ $0.05)$ difference in mortality of lice compared with lower concentrations $(12.5$ and $6.25 \mathrm{mg} / \mathrm{ml})$ of the extracts. In addition, more than $50 \%$ of lice mortality was observed as early as $3 \mathrm{hr}$ after applying the extract at the concentrations of 200 and $100 \mathrm{mg} / \mathrm{ml}$. No mortality of lice was found in the negative control group (treated with distilled water). After $6 \mathrm{hrs}$, moderate mortality percentage up to $73.3 \%$ and $80 \%$ were recorded on lice exposed to 100 and $200 \mathrm{mg} / \mathrm{ml}$ concentrations, respectively. After $12 \mathrm{hr}$ and $24 \mathrm{hr}$ time exposure, 200 and 100mg/ml concentrations of Calpurnea aurea extract showed $93.3 \%, 86.6 \%$ and $100 \%, 96.6 \%$, lice mortality, respectively. The moderate and strong lice mortality percentage (73.3\% and $86.6 \%)$ were recorded after $24 \mathrm{hr}$ at the middle concentration (50 and $25 \mathrm{mg} / \mathrm{ml}$ ) respectively. On the other hand, lower concentrations (12.5 and $6.25 \mathrm{mg} / \mathrm{ml})$ of the extract had weak (60\% and $43.3 \%$ ) louscidal activity against L. vituli after $24 \mathrm{hrs}$ of exposure respectively (Table2).

Table 2: Louscidal activities of different concentrations of the extract of Calpurnia aurea on Linognathus vituli at different times of exposure. 


\begin{tabular}{|c|c|c|c|c|c|c|c|}
\hline \multirow{2}{*}{$\begin{array}{l}\text { Concentration } \\
(\mathrm{mg} / \mathrm{ml})\end{array}$} & \multicolumn{7}{|c|}{ Mean mortaity (\%) \pm SE } \\
\hline & $30 \mathrm{~min}$ & $1 \mathrm{hr}$ & $2 \mathrm{hr}$ & $3 \mathrm{hr}$ & $6 \mathrm{hr}$ & $12 \mathrm{hr}$ & $24 \mathrm{hr}$ \\
\hline 200 & $23.3 \pm 3.3^{a}$ & $36.6 \pm 3.3^{a}$ & $46.6 \pm 3.3^{a}$ & $56.6 \pm 3.3^{a}$ & $80 \pm 0.0^{\mathrm{a}}$ & $93.3 \pm 3.3^{a}$ & $100 \pm 0.0^{a}$ \\
\hline 100 & $13.3 \pm 3.3^{a}$ & $26.6 \pm 3.3^{a}$ & $36.6 \pm 3.3^{a}$ & $53.3 \pm 3^{\mathrm{a}}$ & $73.3 \pm 3.3^{a}$ & $86.6 \pm 3.3^{a}$ & $96.6 \pm 3.3^{a}$ \\
\hline 50 & $10 \pm 0.0^{\mathrm{a}}$ & $13.3 \pm 3.3^{b}$ & $16.6 \pm 3.3^{b}$ & $33.3 \pm 3.3^{\mathrm{ba}}$ & $56.6 \pm 3.3^{\mathrm{b}}$ & $76.6 \pm 3.3^{a}$ & $86.6 \pm 3.3^{\mathrm{a}}$ \\
\hline 25 & $6.6 \pm 3.3^{\mathrm{ba}}$ & $10 \pm 0.0^{\mathrm{b}}$ & $16.6 \pm 3.3^{b}$ & $26.6 \pm 3.3^{b c}$ & $36.6 \pm 3.3^{b}$ & $53.3 \pm 3.3^{\mathrm{ab}}$ & $73.3 \pm 3.3^{b}$ \\
\hline 12.5 & $3.3 \pm 3.3^{\mathrm{ba}}$ & $6.6 \pm 3.3^{b}$ & $6.6 \pm 3.3^{b}$ & $16.6 \pm 3.3^{b c}$ & $33.3 \pm 3.3^{\mathrm{b}}$ & $46.6 \pm 3.3^{\mathrm{ab}}$ & $60.0 \pm 5.7^{b}$ \\
\hline 6.25 & $0 \pm 0.0^{\mathrm{ba}}$ & $3.3 \pm 3.3^{b}$ & $6.6 \pm 3.3^{b}$ & $13.3 \pm 3.3^{b c}$ & $23.3 \pm 3.3^{\mathrm{ba}}$ & $33.3 \pm 3.3^{\mathrm{ab}}$ & $43.3 \pm 3.3^{b}$ \\
\hline $\begin{array}{l}\text { Diazinon } \\
0.1 \%\end{array}$ & $13.3 \pm 3.3^{a}$ & $20 \pm 0.0^{\mathrm{a}}$ & $36.6 \pm 3.3^{a}$ & $46.6 \pm 3.3^{\mathrm{a}}$ & $76.6 \pm 3.3^{a}$ & $90 \pm 0.0^{\mathrm{a}}$ & $96.6 \pm 3.3^{a}$ \\
\hline Distilled H2O & $0 \pm 0.0^{\mathrm{b}}$ & $0 \pm 0.0^{\mathrm{b}}$ & $0 \pm 0.0^{\mathrm{b}}$ & $0 \pm 0.0^{\mathrm{ab}}$ & $0 \pm 0.0^{b c}$ & $0 \pm 0.0^{b}$ & $0 \pm 0.0^{\mathrm{b}}$ \\
\hline
\end{tabular}

Means followed by the same letter on the same column are not significantly different $(P>0.05)$

SE- standard error, hr- hour

In vitro louscidal activity test of Schinus molle crude extract showed that the mortality of lice was gradually increased with increase post-exposure time and the concentration of the extracts as shown in figure 2.

The different concentrations of methanol extracts of $S$. molle leaf extract were evaluated for their louscidal properties against $L$. vitulli. The mean mortalities of lice treated with different concentrations of the extract are shown in table 3 . The results showed that all concentrations of methanolic extract of $S$. molle have no louscidal activity at 30 minutes. However, after $12 \mathrm{hrs}$ of exposure, higher mortality percentage (> $50 \%)$ was recorded on lice exposed to 200, 100 and $50 \mathrm{mg} / \mathrm{ml}$ concentrations of the extract. All concentrations of the extract showed a statically significant difference $(P<0.05)$ in their louscidal activity at different times of exposure, except 200 and $100 \mathrm{mg} / \mathrm{ml}$ concentration of the extract after $24 \mathrm{hr}$ exposure as compared to the positive control. Accordingly, after $24 \mathrm{hrs}$ of exposure to 200 and $100 \mathrm{mg} / \mathrm{ml}$ concentrations showed mortality of $90.0 \%$ and $83.3 \%$, respectively. In contrary, lower concentrations $(12.5$ and $6.25 \mathrm{mg} / \mathrm{ml}$ ) of the extract showed no louscidal activity up to $3 \mathrm{hr}$ and had little or weak louscidal activity ranging from 36 to $40 \%$ mortality against L. vituli after $24 \mathrm{hrs}$ of exposure. The highest concentrations (200 and $100 \mathrm{mg} / \mathrm{ml}$ ) have showed strong efficacy of lice mortality up to $90 \%$ and $83.3 \%$, respectively. Compared to the negative control (distilled water) all concentrations of the extract showed high mortality of lice (Table 3).

Table 3: Louscidal activities of different concentrations of the extract of Schinus molle on Linognathus vituli at different times of exposure 


\begin{tabular}{|c|c|c|c|c|c|c|c|}
\hline \multirow{2}{*}{$\begin{array}{l}\text { Concentration } \\
(\mathrm{mg} / \mathrm{ml})\end{array}$} & \multicolumn{5}{|c|}{ Mean mortality $(\%) \pm S E$} & \multirow[b]{2}{*}{$12 \mathrm{hr}$} & \multirow[b]{2}{*}{$24 \mathrm{hr}$} \\
\hline & $30 \mathrm{~min}$ & $1 \mathrm{hr}$ & $2 \mathrm{hr}$ & $3 \mathrm{hr}$ & $6 \mathrm{hr}$ & & \\
\hline 200 & $0 \pm 0.0^{\mathrm{a}}$ & $6.6 \pm 3.3^{\mathrm{a}}$ & $10 \pm 0.0^{\mathrm{a}}$ & $16.6 \pm 3.3^{a}$ & $46.6 \pm 3.3^{a}$ & $70 \pm 5.7^{a}$ & $90 \pm 5.7^{\mathrm{a}}$ \\
\hline 100 & $0 \pm 0.0^{a}$ & $3.3 \pm 3.3^{a}$ & $6.6 \pm 3.3^{\mathrm{a}}$ & $13.3 \pm 6.6^{a}$ & $36.6 \pm 3.3^{a}$ & $56.6 \pm 3.3^{a}$ & $83.3 \pm 3.3^{a}$ \\
\hline 50 & $0 \pm 0.0^{\mathrm{a}}$ & $3.3 \pm 3.3^{a}$ & $3.3 \pm 3.3^{\mathrm{a}}$ & $10 \pm 0.0^{\mathrm{a}}$ & $23.3 \pm 3.3^{\mathrm{ba}}$ & $50 \pm 5.7^{\mathrm{a}}$ & $66.6 \pm 3.3^{a}$ \\
\hline 25 & $0 \pm 0.0^{a}$ & $0 \pm 0.0^{\mathrm{a}}$ & $3.3 \pm 3.3^{\mathrm{a}}$ & $6.6 \pm 3.3^{\mathrm{a}}$ & $20 \pm 0.0^{\text {ba }}$ & $30 \pm 5.7^{b}$ & $56.6 \pm 3.3^{b}$ \\
\hline 12.5 & $0 \pm 0.0^{\mathrm{a}}$ & $0 \pm 0.0^{\mathrm{a}}$ & $3.3 \pm 3.3^{\mathrm{a}}$ & $3.3 \pm 3.3^{\mathrm{a}}$ & $16.6 \pm 3.3^{\text {ba }}$ & $23.3 \pm 3.3^{b}$ & $40 \pm 5.7^{b}$ \\
\hline 6.25 & $0 \pm 0.0^{\mathrm{a}}$ & $0 \pm 0.0^{\mathrm{a}}$ & $0 \pm 0.0^{\mathrm{a}}$ & $3.3 \pm 3.3^{a}$ & $10 \pm 5.7^{\text {ba }}$ & $23.3 \pm 3.3^{b}$ & $36.6 \pm 3.3^{b}$ \\
\hline Diazinon $0.1 \%$ & $16.6 \pm 3.3^{b}$ & $20 \pm 5.7^{b}$ & $30 \pm 5.7^{b}$ & $43.3 \pm 3.3^{b}$ & $70 \pm 5.7^{b}$ & $83.3 \pm 3.3^{a}$ & $93.3 \pm 3.3^{a}$ \\
\hline Distilled H2O & $0 \pm 0.0^{a}$ & $0 \pm 0.0^{\mathrm{a}}$ & $0 \pm 0.0^{\mathrm{a}}$ & $0 \pm 0.0^{\mathrm{a}}$ & $0 \pm 0.0^{\mathrm{bac}}$ & $0 \pm 0.0^{\mathrm{ba}}$ & $0 \pm 0.0^{\mathrm{ba}}$ \\
\hline
\end{tabular}

Means followed by the same letter on the same column are not significantly different $(P>0.05)$

SE- standard error, hr- hour

\section{Toxic effect}

Table 4 shows the results of the toxic effects of the plant extracts against Linognatus vituli. Accordingly, toxicity varied with the plant extract and adult lice feeding time. After 24 hours of exposure to the extracts, the highest mortality was recorded for extracts from $C$. aurea with $\mathrm{LC}_{50}$ values of $8.83 \mathrm{mg} / \mathrm{ml}$ compared to S.molle with $\mathrm{LC}_{50}$ values of $16.68 \mathrm{mg} / \mathrm{ml}$.

Table 4: Louscidal activity of plant extracts against Linognathus vituli after $24 \mathrm{hr}$ of exposure

\begin{tabular}{|c|c|c|c|c|c|}
\hline $\begin{array}{l}\text { Plant } \\
\text { extract }\end{array}$ & $x^{2}$ & $\begin{array}{l}\text { Regression } \\
\text { equation }\end{array}$ & $\begin{array}{l}\mathrm{LC}_{50}(\mathrm{mg} / \mathrm{ml}) \\
(95 \% \mathrm{Cl})\end{array}$ & $\begin{array}{l}\mathbf{L C}_{90}(\mathbf{m g} / \mathbf{m l}) \\
(95 \% \mathrm{Cl})\end{array}$ & $\begin{array}{l}\mathbf{L C}_{\mathbf{9 9}}(\mathbf{m g} / \mathbf{m l}) \\
(95 \% \mathrm{Cl})\end{array}$ \\
\hline C. aurea & 4.79 & $y=1.63 x-1.54$ & $\begin{array}{l}8.83 \\
(5.06,12.61)\end{array}$ & $\begin{array}{l}53.83 \\
(36.63,101.55)\end{array}$ & $235.04(119.00,859.61)$ \\
\hline S. molle & 5.12 & $y=1.12 x-1.37$ & $\begin{array}{l}16.68 \\
(9.29,25.15)\end{array}$ & $\begin{array}{l}230.42 \\
(120.52,815.50)\end{array}$ & $\begin{array}{l}1959.42 \\
(610.93,22,159.65)\end{array}$ \\
\hline
\end{tabular}

LC50 LC90 and LC99 are lethal concentration that kills 50\%, $90 \%$ and $99 \%$ of the ingesting lice respectively, $95 \% \mathrm{Cl}$ is the $95 \%$ Confidence Interval of the estimate, $\chi 2$ chi-square values.

The log (concentration)-mortality trends of $C$. aurea and $S$. molle shows, the gradual increase in mortality of lice as the log (concentration) value increases (Figure 3).

\section{Discussion}


The use of natural products, mainly insecticide and acaricide from the botanical source used for the control of ectoparasite has been the focus of research in many countries, principally to withstand the noticeable increasing frequency of drug-resistant parasite strains.

The present study revealed that there was a difference in yield percentage of extracts among the plants (Table 1). The leaf of $S$. molle presented the highest yield (6\%) compared to $C$. aurea (4\%). This finding was in contrary with (23) who reported $19.33 \%$ and $20.67 \%$ for methanolic leaf extract of $S$. molle and $C$. aurea, respectively. The differences on the yield of these extract materials could be attributed to the difference in chemical composition of the extracts, environmental conditions which create differences in phytochemical constitution, and harvest time. Furthermore, the solvents and test protocols used during extraction promote difference in concentrations and classes of secondary bioactive present in extracts (23).

The current study revealed that the two plant extracts (Calpurnea aurea and Schinus molle) demonstrated highly appreciable louscidal activity at different concentrations and exposure time. This finding is in line with the reports of (24) who concludes mortality effect of botanicals was concentration and exposure time dependent. Our study also revealed that methanolic extracts of the two plants at tested concentrations induced significant acaricidal effect against $L$. vituli compared with the negative control.

The in vitro lice killing activity of methanolic leaf extracts of $C$. aurea is increased with increased concentrations and time exposure (Table 2). All concentrations of Calpurnea aurea leaf extract showed louscidal activities when compared to the negative control. More than $50 \%$ of lice mortality was observed as early as $3 \mathrm{hr}$ after applying the extract at the concentrations of 200 and $100 \mathrm{mg} / \mathrm{ml}$. Two higher concentrations (200 and 100mg/ml) of Calpurnea aurea extract poses strong mortality percentages (100\% and $96 \%$ ) after $24 \mathrm{hr}$ post-exposure, respectively (Table2). In addition, Calpurnea aurea extracts of $50 \mathrm{mg} / \mathrm{ml}$ and above concentration have shown no significant difference $(P>0.05)$ on mortality of lice after 24 hours of post-exposure when compared with Diazinon $0.1 \%$. Lower concentration $(12.5 \mathrm{mg} / \mathrm{ml}$ and $6.25 \mathrm{mg} / \mathrm{ml})$ of Calpurnea aurea extract possess weak mortality percentage (60\% and $43 \%)$; which is not significantly different $(P>0.05)$ compared with two higher concentrations. However, no report exists in the literature concerning the louscidal activity of the extract of $C$. aurea against L. vtuli, although (13); has documented their insecticidal properties and (15); was reported strong lice (L. ovillius) mortality percentage after $24 \mathrm{hr}$ exposure time. Although there is a difference in the species of lice evaluated, the current finding is in agreement to the findings of (15). The variability in the mortality percentage of lice could be attributed due to species differences and time of collection of the plant material. In a previous study, it has been reported that the insecticidal properties of some plant extracts could be due to the involvement of anticholinergic alkaloids such as scopolamine, hyoscyamine, meteloidine, and atropine (25).

As far as our literature search is concerned, no study was reported on louscidal efficacy of Schinus molle. However, in folk medicine, Schinus molle is an extensively studied medicinal plant throughout the world and has been reported to be used against wide ranges of human and livestock ailments $(11,18,19)$. In Ethiopia, its leaves are used as natural repellents against insects such as flies (27). The current finding showed that, after $24 \mathrm{hr}$ post exposure, higher concentration (200 and $100 \mathrm{mg} / \mathrm{ml}$ ) of Schinus molle extracts showed strong lice mortality $(90 \%$ and $83.3 \%$ ) respectively. In addition, Schinus molle extract at a concentration of $200 \mathrm{mg} / \mathrm{ml}$ and $100 \mathrm{mg} / \mathrm{ml} \mathrm{have}$ showed no significance $(P>0.05)$ difference after $24 \mathrm{hr}$ exposure when compared with Diazinon $0.1 \%$. This implies higher concentrations had comparable effect with the reference drugs. The results showed that all concentrations of methanolic extract of Schinus molle showed no louscidal activity at 30 minutes. However, after 
$12 \mathrm{hrs}$ of exposure, higher mortality percentage more than $50 \%$ was recorded on lice exposed to three higher (200, 100 and $50 \mathrm{mg} / \mathrm{ml}$ ) concentration (Table 3). Lower concentration $(12.5 \mathrm{mg} / \mathrm{ml}$ and $6.25 \mathrm{mg} / \mathrm{ml}$ ) of Schinus molle extract, possess little or no activity of lice mortality and showed significance difference $(P<0.05)$ when compared with two higher concentrations (200 and $100 \mathrm{mg} / \mathrm{ml})$.

The current study demonstrated that the methanolic extracts of Calpurnea aurea and Schinus molle have a lethal effect against Linognathus vitulli. We found a relatively higher louscidal activity of the extract from $C$. aurea $\left(\mathrm{LC}_{50} 8.83 \mathrm{mg} / \mathrm{ml}\right)$ compared to the extracts from S. molle ( $\mathrm{LC}_{50}$ 16.68) after $24 \mathrm{hr}$ exposure. Moreover, from the calculated $\mathrm{LC}_{50}, \mathrm{LC}_{90}$ and $\mathrm{LC}_{99}$ values after $24 \mathrm{hr}$ exposure (Table 4), it is clearly seen the effect of the extracts against lice were dose-dependent. As a result, mean mortality percentage increases with increase in the concentration of the extract.

\section{Conclusion}

The extracts of Calpurnea aurea and Schinus molle leaf were tested against $L$. vitulli for their killing efficacy at different concentrations and time intervals. The louscidal activity of the extracts increases with increasing concentration and exposure time. The findings suggest that the crude methanol extracts of the plants possess loucidal activity, which was comparable to the effect of the reference drug, Diazinon $0.1 \%$ at higher concentrations. Calpurnea aurea had strong activity and possess higher mortality rate than reference drug, Diazinon $0.1 \%$ after $24 \mathrm{hr}$ after exposure to the concentration of $200 \mathrm{mg} / \mathrm{ml}$. Moreover, $C$. aurea had much better efficacy against the lice than the Schinus molle and reference drug, Diazinon $0.1 \%$. Therefore, the present study concluded that, Calpurnea aurea and Schinus molle could be used as potential alternative for control of lice.

\section{Abbreviations}

AIT: Adult Immersion Test

LC: Lethal Concentration

CSA: central Statistical Authority

GDP: Gross Domestic Product

FAO: Food and Agricultural Organization

EVM: Ethno Veterinary Medicine

SE: Standard Error

95\%Cl: 95\% Confidence Interval

$\chi 2$ : Chi square value

\section{Declarations}

\section{Ethics approval and consent to participate}


Not Applicable.

\section{Consent for publication}

Not Applicable.

\section{Competing interests}

The authors declare that they have no competing interests.

\section{Author's contributions}

Abdi $A$ and $A D$ conceived designed the experiment. $A D$ and Alula A. supervised the experiment. Abdi $A$. experimented. Alula A. statistical analysis and interprets the findings. Abdi A. drafted the manuscript. Alula A. commented and made the final suggestions in the manuscript. All authors approved the final version for submission.

\section{Acknowledgements}

The authors gratefully acknowledge Haramaya University, College of Veterinary Medicine for allowing their laboratory and providing materials during the laboratory work. Comments made by Dr. Ahmed Yasin are gratefully acknowledged.

\section{Availability of data and materials}

The datasets and script code used and/or analyzed during the current study are available from the corresponding author on reasonable request.

\section{References}

1. Patz T. Ethiopia (Federal Democratic Republic of Ethiopia). Handb Fed Countries, 2005. 2005;II(March):13648.

2. Solomon A, Workalemahu A, Jabbar MA, Ahmed MM, Hurissa B. Livestock marketing in Ethiopia: a review of structure, performance, and development initiatives. Socio-economics Policy Res Work Pap 52. 2003;32.

3. Kumsa B, Tamrat H, Tadesse G, Aklilu N, Cassini R. Prevalence and species composition of ixodid ticks infesting horses in three agroecologies in central Oromia, Ethiopia. Trop Anim Health Prod. 2012;44(1):11924.

4. Cotter J, Pearson J. Sheep lice spread and detection | Agriculture and Food [Internet]. 2019 [cited 2021 Feb 19]. Available from: https://www.agric.wa.gov.au/livestock-parasites/sheep-lice-spread-and-detection

5. Clark TG, Bradburn MJ, Love SB, Altman DG. Survival Analysis Part I: Basic concepts and first analyses. Br J Cancer. 2003;89(2):232-8.

6. Iqbal Z, Akhtar M, Sindhu Z, Khan M, Jabbar A. Herbal dewormers in livestock-a traditional therapy. Int J Agr Biol. 2003;5(2):199-206.

7. Zorloni A, Penzhorn BL, Eloff JN. Extracts of Calpurnia aurea leaves from southern Ethiopia attract and immobilise or kill ticks. Vet Parasitol. 2010;168(1-2):160-4.

8. Habeeb SM. Plants in Tick Control.Pdf. World Applied Sciences. 2010. 
9. McGaw LJ, Van der Merwe D, Eloff JN. In vitro anthelmintic, antibacterial and cytotoxic effects of extracts from plants used in South African ethnoveterinary medicine. Vet J. 2007;173(2):366-72.

10. Muhammad G, Khan MZ, Hussain MH, lqbal Z, Iqbal M, Athar M. Ethnoveterinary practices of owners of pneumatic-cart pulling camels in Faisalabad City (Pakistan). J Ethnopharmacol. 2005;97(2):241-6.

11. Nchu F, Magano SR, Eloff JN. In vitro anti-tick properties of the essential oil of Tagetes minuta L. (Asteraceae) on Hyalomma rufipes (Acari: Ixodidae). Onderstepoort J Vet Res. 2012;79(1):1-5.

12. Tadeg H, Mohammed E, Asres K, Gebre-Mariam T. Antimicrobial activities of some selected traditional Ethiopian medicinal plants used in the treatment of skin disorders. J Ethnopharmacol. 2005;100(1-2):16875.

13. Erazo S, Delporte C, Negrete R, García R, Zaldívar M, Iturra G, et al. Constituents and biological activities of Schinus polygamus. J Ethnopharmacol. 2006;107(3):395-400.

14. Guala MS, Elder H V., Perez G, Chiesa A. Evaluación del poder antioxidante de fracciones de aceite esencial crudo de Schinus molle L. obtenidas por destilación al vacío. Inf Tecnol. 2009;20(2):83-8.

15. Morka. IN VITRO LOUSCIDAL AND ACARICIDAL ACTIVITIES OF ALKALOID OF CALPURNIA AUREA AND FRACTIONS OF RICINUS COMMUNIS EXTRACTS AGAINST LINOGNATHUS OVILLUS AND AMBLYOMMA VARIEGATUM. Vol. 42. 2016.

16. Magano S. R. Repellent properties of Nicotiana tabacum and Eucalyptus globoidea against adults of Hyalomma marginatum rufipes. African J Microbiol Res. 2011;5(26):4508-12.

17. Wall R, Shearer D. Veterinary Ectoparasites: Biology, Pathology and Control: Second Edition. Vet Ectoparasites Biol Pathol Control Second Ed. 2008;1-262.

18. Heukelbach J, Speare R, Canyon D. Natural products and their application to the control of head lice: an evidence-based review. Sect Title Pharm. 2006;661(2):277-302.

19. Nana P, Maniania NK, Maranga RO, Kutima HL, Boga HI, Nchu F, et al. Attraction response of adult Rhipicephalus appendiculatus and Rhipicephalus pulchellus (Acari: Ixodidae) ticks to extracts from Calpurnia aurea (Fabaceae). Vet Parasitol. 2010;174(1-2):124-30.

20. Krishnaveni S, Venkatalakshmi P. Antimicrobial, Larvicidal and Acaricidal Activities of the Ethanolic Extract of Andrographis Paniculata and Carica Papaya Leaves. World J Pharm Res. 2014;3(4):660-9.

21. Gemeda N, Mokonnen W, Lemma H, Tadele A, Urga K, Addis G, et al. Insecticidal activity of some traditionally used Ethiopian medicinal plants against sheep ked Melophagus ovinus. J Parasitol Res. 2014;2014.

22. R Core Team. R: The R Project for Statistical Computing [Internet]. 2019 [cited 2021 Feb 19]. Available from: https://www.r-project.org/

23. Kemal J, Zerihun T, Alemu S, Sali K, Nasir M, Abraha A, et al. In Vitro Acaricidal Activity of Selected Medicinal Plants Traditionally Used against Ticks in Eastern Ethiopia. J Parasitol Res. 2020;2020.

24. Qwarse Michael, Mihale Matobola, Henry Leonia, Sempombe Joseph, Mugoyela Veronica SF. Assessment of Bioactivity of Se-lected Plants against Pests and Microbes from Agro-pastoral Communities in Mbulu District, Tanzania. J Food Secur. 2016;4(6):147-55.

25. Doncheva T, Berkov S, Philipov S. Comparative study of the alkaloids in tribe Datureae and their chemosystematic significance. Biochem Syst Ecol. 2006;34(6):478-88.

26. Machado DG, Kaster MP, Binfaré RW, Dias M, Santos ARS, Pizzolatti MG, et al. Antidepressant-like effect of the extract from leaves of Schinus molle L. in mice: Evidence for the involvement of the monoaminergic

Page $11 / 14$ 
system. Prog Neuro-Psychopharmacology Biol Psychiatry. 2007;31(2):421-8.

27. Bogdadi HAA, Kokoska L, Havlik J, Kloucek P, Rada V, Vorisek K. In vitro antimicrobial activity of some Libyan medicinal plant extracts. Pharm Biol. 2007;45(5):386-91.

\section{Figures}

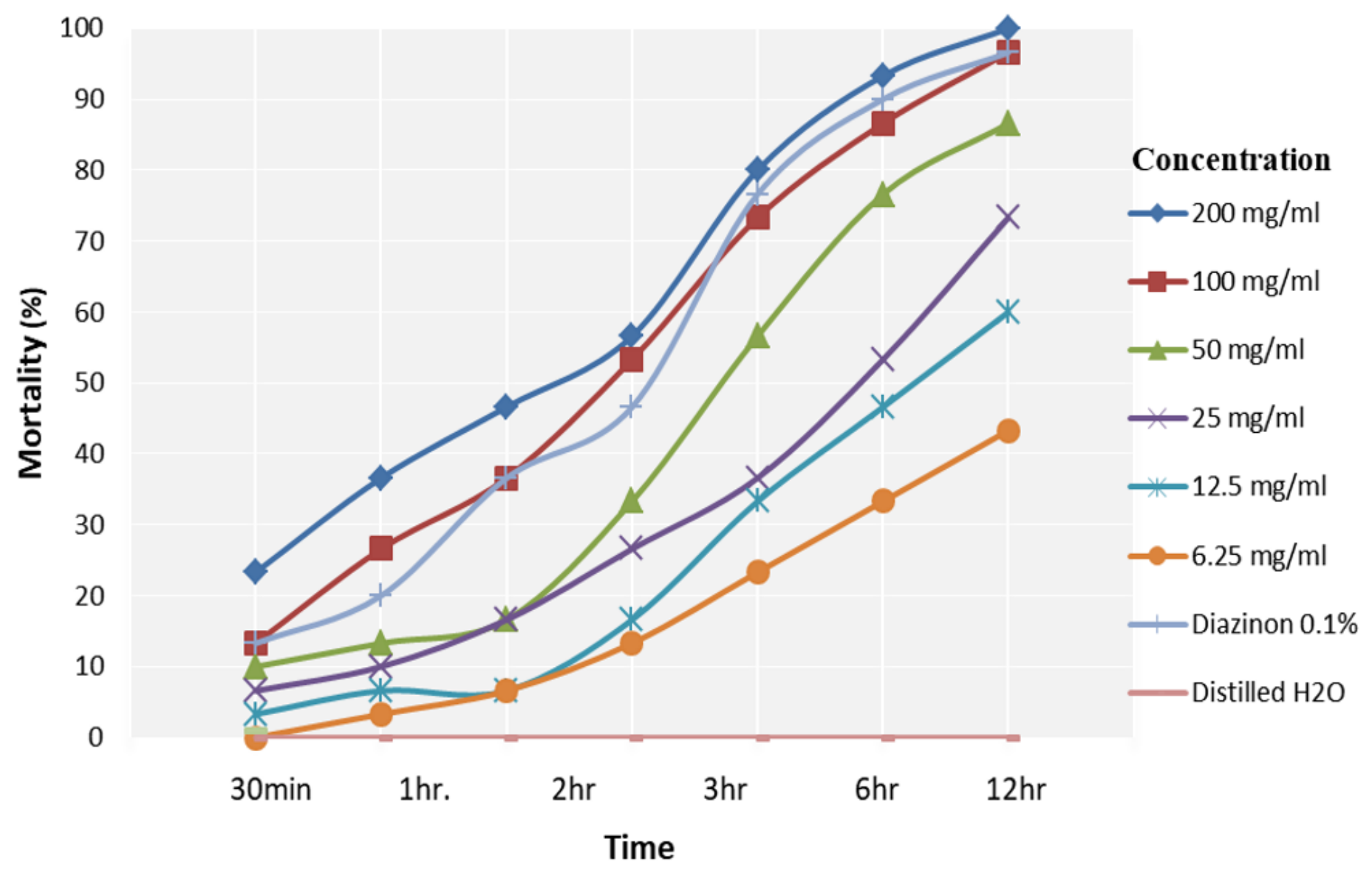

Figure 1

The effect of methanolic extract of Calpurnea aurea on mortality of Linognatus vituli exposed to different extract concentrations 


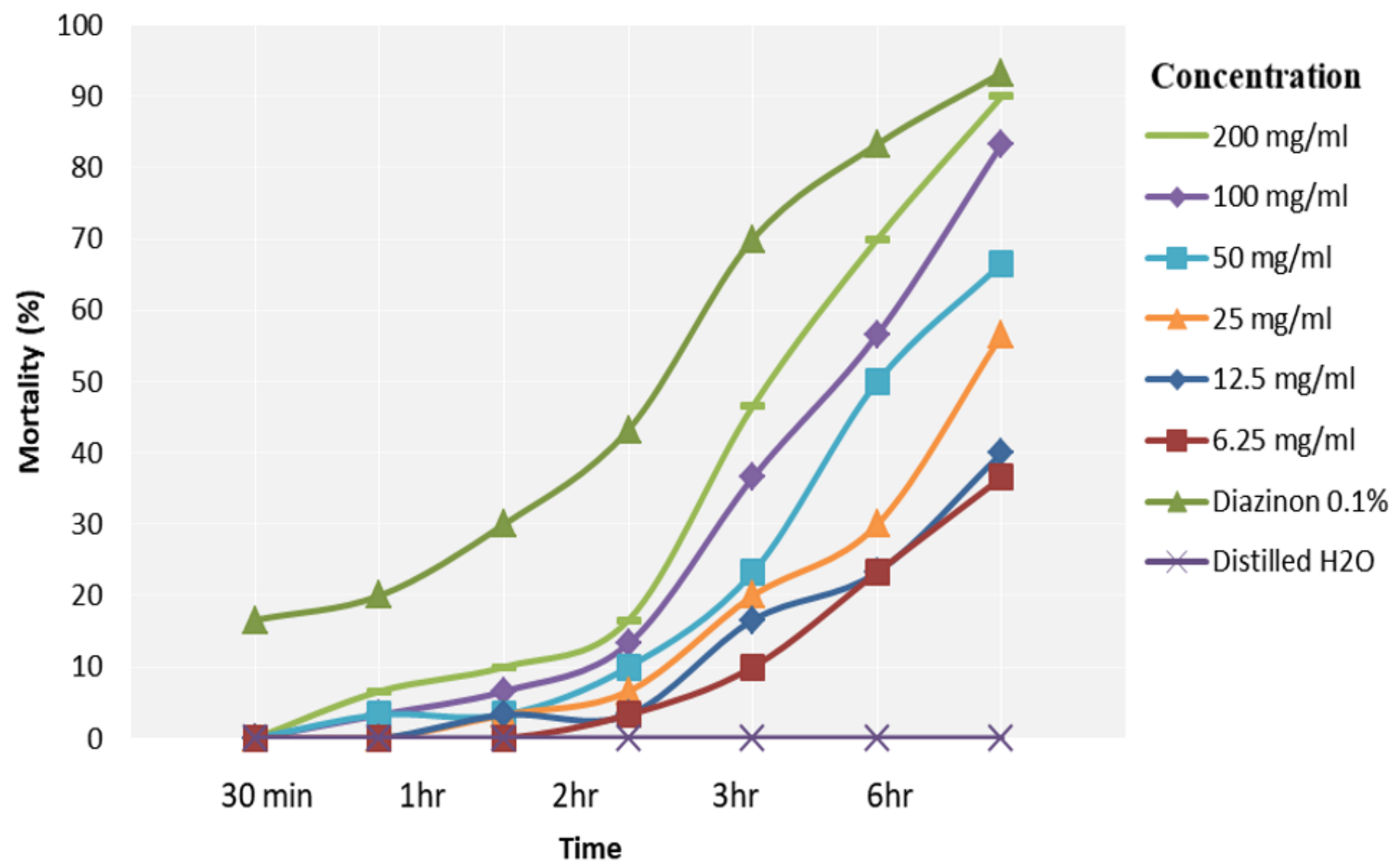

Figure 2

The effect of methanolic extract of Schinus mole on mortality of Linognatus vituli exposed to different concentrations of the extract 


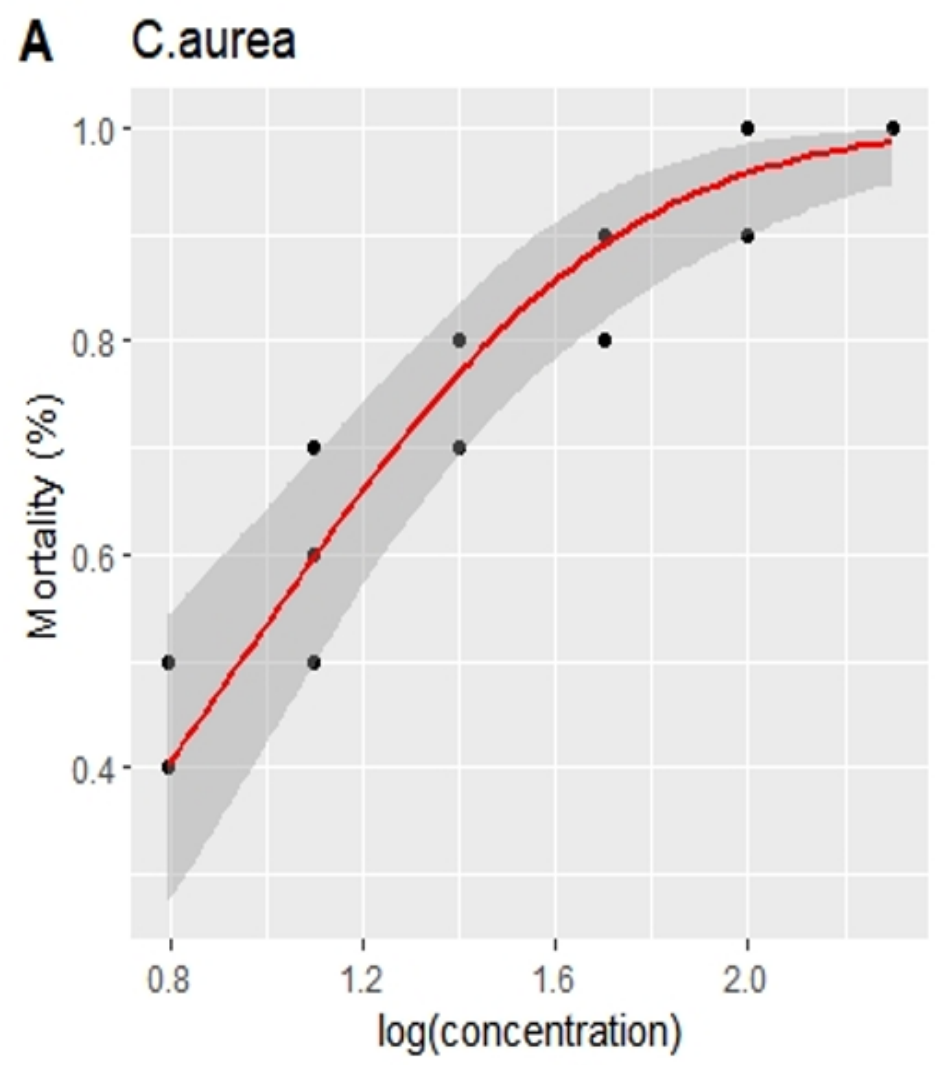

B S.mole

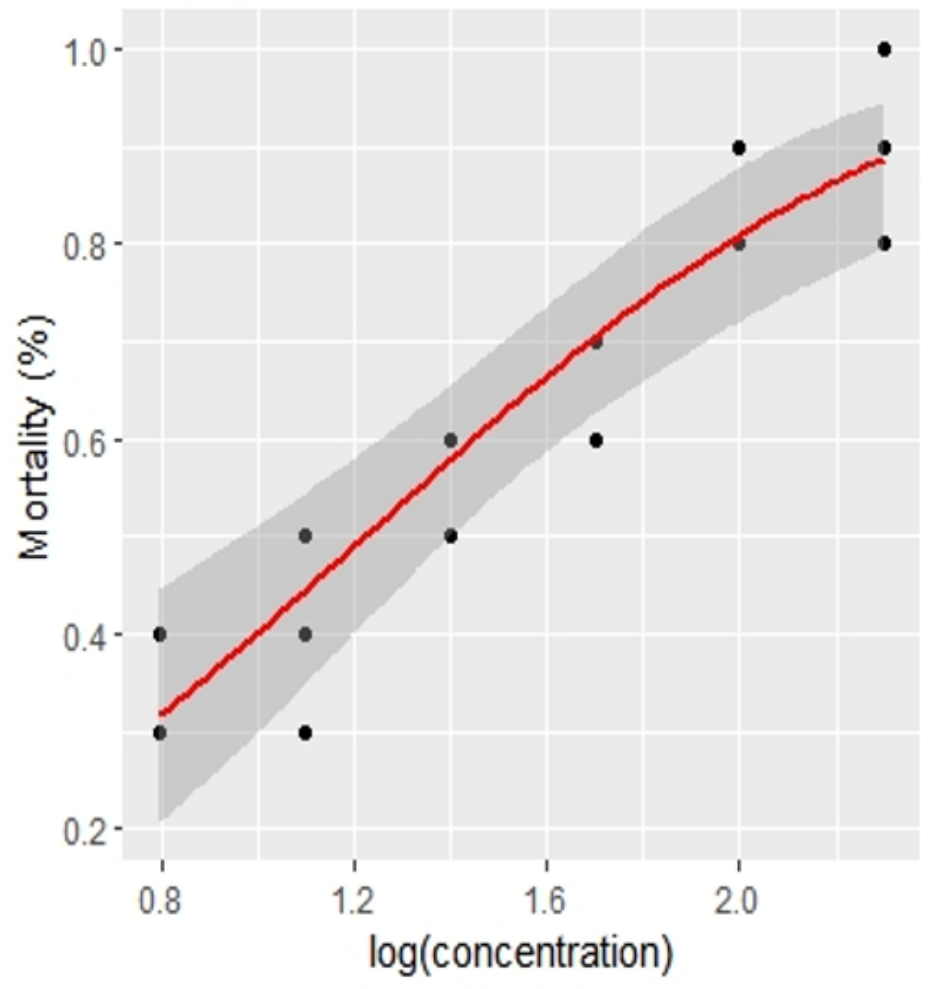

Figure 3

Log (concentration) - mortality plot of Linognathus vituli exposed to a various doses of C. aurea and S. molle extract after $24 \mathrm{hr}$ time exposure. 